\title{
Crested wheatgrass and shrub response to continuous or rotational grazing
}

\author{
RAYMOND F. ANGELL
}

Author is range scientist with USDA-ARS at the Eastern Oregon Agricultural Research Center, HC-71, 4.51, Hwy 205, Burns, Ore. 97720.

\begin{abstract}
A four-year study was conducted to investigate effects of continuous and short duration grazing in spring on standing crop and tiller density of crested wheatgrass [Agropyron desertorum (Fisch. ex Link) Schult], along with changes in cover and density of Wyoming big sagebrush (Artemisia tridentata Nutt. subsp. wyomingensis Beetle and Young) and green rabbitbrush [Chrysothamnus viscidiflorus (Hook.) Nutt.]. Eight pastures were each stocked with 10 steers $(224 \mathrm{~kg})$ beginning in early May. Four grazing treatments consisted of continuous grazing at 0.6 AUM/ha (CONT) or short duration grazing management at 0.6, 0.9 , and 1.2 AUM/ha for LOW, MED, and HIGH treatments, respectively. After 4 years, mean tiller density was greatest on LOW paddocks $(P=0.10)(707$ tillers/m²). Tiller density on HIGH paddocks did not differ $(P>0.05)$ from CONT. Density of large ( $>$ $15-\mathrm{cm}$ tall) Wyoming big sagebrush increased $(P \leq 0.05)$ across years, but did not vary $(P>0.05)$ among treatments, at about 9 plants $/ 100 \mathrm{~m}^{2}$. Sagebrush plants $<15-\mathrm{cm}$ tall responded differently $(P=0.02)$ in CONT compared to HIGH. Small sagebrush density increased under short duration grazing at doubled stocking rate (HIGH) compared to CONT, but LOW and MED did not differ from CONT. We concluded that short duration rotation grazing at a conventional stocking rate decreased neither tillering nor yield of crested wheatgrass. Shrub density and cover changes on LOW were similar to CONT. It does appear, however, that short duration grazing at the doubled stocking rate has the potential to limit crested wheatgrass productivity over time because of enhanced sagebrush seedling survival.
\end{abstract}

Key Words: short duration grazing, Agropyron desertorum, sagebrush, Artemisia tridentata, green rabbitbrush, Chrysothamnus viscidiflorus, tiller dynamics, cover, density.

Crested wheatgrass [Agropyron desertorum (Fisch. ex Link) Schult] has been seeded extensively in the northern and western U.S. The species is well adapted to grazing and provides excellent forage for livestock in spring (Cook and Harris 1968). After establishment, crested wheatgrass stands are nearly monospecific, but reinvasion of Wyoming big sagebrush (Artemisia tridentata Nutt. subsp. wyomingensis Beetle and Young) often occurs and periodic control is necessary (Evans et al. 1986).

Although sagebrush can re-establish in crested wheatgrass

\footnotetext{
The Eastern Oregon Agricultural Research Center including the Northern Great Basin Experimental Range, the Burns Station and the Union Station, is jointly operated by the USDA Agricultural Research Service and Oregon Agricultural Experiment Station.

Manuscript accepted 6 Apr. 1996
}

seedings, establishment may be limited unless individual plants or residual seeds survive the seeding treatment (Marlette and Anderson 1986). Rate of establishment can also be influenced by grazing intensity, season of use, grazing system and kind of livestock used (Laycock 1967, Robertson et al. 1970, Laycock and Conrad 1981). Short duration grazing was popularized in the early 1980 's and has the potential to improve utilization of rangelands because of enhanced livestock distribution and better control over timing and intensity of defoliation (Kothmann 1980, Savory and Parsons 1980). As part of short duration grazing management, pastures are usually subdivided and stocking density greatly increased, which alters plant-animal interactions. Issues regarding animal performance have received wide attention (Heitschmidt and Taylor 1991), however, few pasture-scale short duration grazing studies have investigated shrub and/or grass dynamics on crested wheatgrass pastures (Sanders et al. 1986; Olson and Richards 1988a, 1988b; Owens and Norton 1990).

In the present study, we compared short duration grazing management to continuous grazing over a 4-year period. Objectives of this research were to determine the effect of continuous and short duration grazing during spring on tiller dynamics of crested wheatgrass and to measure relative changes in shrub density and cover.

\section{Materials and Methods}

The study was conducted at the Northern Great Basin Experimental Range (119 $43^{\prime} \mathrm{W}, 43^{\circ} 29^{\prime} \mathrm{N}$; $1,370 \mathrm{~m}$ elev.) approximately $72-\mathrm{km}$ west-southwest of Burns, Ore. Mean annual precipitation is $28.3 \mathrm{~cm}$ with peak accumulation in November, December, January, and May (Table 1).Herbaceous yields are highly correlated with September to August precipitation (Sneva 1977). Mean annual temperature is about $7.6^{\circ} \mathrm{C}$. The 52 -ha study site originally supported a Wyoming big sagebrush-Idaho fescue (Festuca idahoensis Elmer) community, but was disked and seeded to crested wheatgrass in 1967 . Soils are predominantly Holtle Series coarse-loamy, mixed, frigid Aridic Duric Haploxerolls (Lentz and Simonson 1986). The area had been grazed moderately (0.6-0.8 AUM/ha) by cattle in May and June until initiation of this study.

The study was established in 1984 (year 1) and continued through 1987 (year 4). During the 4-year study, grazing began in May during the boot stage of phenology. Each year, 80 yearling steers $(224 \mathrm{~kg})$ were randomly allocated by weight to 8 treatment groups. One steer was considered to provide 0.6 animal units of forage demand. Four grazing treatments in 2 blocks were used, 
consisting of continuous (CONT) grazing for 45 days at 0.6 $\mathrm{AUM} / \mathrm{ha}$, or short duration grazing at $0.6,0.9$, or $1.2 \mathrm{AUM} / \mathrm{ha}$ (LOW, MED, and HIGH, respectively'), using two 3-day graze periods separated by a 27 -day rest. The CONT treatment pastures were 15 ha in size. Short duration pastures were 2, 1.3, and 1 ha in size for LOW, MED, and HIGH, respectively, to achieve the desired stocking rates. Short duration grazed treatment pastures represented 1 pasture of a 10 -pasture rotation. One exception to these grazing treatments occurred in 1986 when animals remained in short duration pastures for 5 days. Pastures were grazed only once that year. Animal performance was not recorded during the study because resource constraints precluded building 6 complete 10-paddock short durition grazed units. Steers were on short duration grazed paddocks for only 6 days each year, and therefore any weight changes noted could not have been attributed to treatments.

Prior to grazing in year 1, permanent plots were randomly located in each of the 8 pastures to monitor crested wheatgrass tiller density. Five belts $(4 \mathrm{~cm} \times 300 \mathrm{~cm})$, spaced $5 \mathrm{~m}$ apart, were established in each pasture by driving stakes to within $2 \mathrm{~cm}$ of the soil surface at 4 randomly located positions ( 20 belts/pasture). During the late vegetative stage each spring, wire was stretched around the stakes to establish the belt. All live tillers occurring within each belt were counted. Wires were removed each year after sampling.

Sagebrush and green rabbitbrush [Chrysothamnus viscidiflorus (Hook.) Nutt.] foliar cover and plant density were monitored each year during late June or early July. In year 1, a permanent 30-m line transect was established near each of the 4 tiller counting locations in each pasture. Foliar cover was estimated by line intercept, and plant density was estimated by counting all live plants within a permanent $2 \times 30-\mathrm{m}$ belt centered over each line transect.

Crested wheatgrass standing crop was estimated each spring by clipping 10 randomly placed $1-\mathrm{m}^{2}$ quadrats in each pasture just prior to grazing. Forage was clipped to ground level, dried at $60^{\circ} \mathrm{C}$ for 48 hours, and weighed.

Statistical analysis was conducted using the general linear models procedure of SAS (1985). Data were analyzed as a split-plot in time (Steel and Torrie 1980), with 2 replications. Differences between treatments are difficult to detect with only 2 replications, however, livestock and land resource limitations did not permit a larger design. The 8 paddocks were considered experimental units, with grazing treatments assigned to main plots and years to split plots (Petersen 1985). Grazing by replication interaction was the main plot error. Error for year and grazing by year interaction was the 3-way interaction term. Where significance of main effects was detected, means were separated using LSD (Peterson
1985). When year by grazing interaction was significant, the data were analyzed within year. Unless otherwise stated, statistical significance was assessed at $\mathrm{P} \leq 0.05$. Sums of squares for years were partitioned into linear and quadratic effects using orthogonal polynomials (Steel and Torrie 1980).

\section{Results and Discussion}

\section{Growing Conditions}

Precipitation was highly variable between years (Table 1). Crop year (September-August) precipitation was $47 \%$ above average the first year of the study, while in the second year (1984-1985) it was $25 \%$ below average. Total precipitation was near average during the 1986 and 1987 crop years. Annual variation of late winter and early spring precipitation probably had a major influence on plant growth and development. Monthly totals were consistently below historical mean values for the 1984-85 crop year, which resulted in a shorter growing season than the previous and following years. August, September, and October precipitation and temperature varied each year of the study. Recent research at this location (Miller and Rose 1992) and by Mueller and Richards (1986) in Utah indicates the observed variability in fall precipitation was probably a major factor determining crested wheatgrass tiller density the following growing season. This may account for much of the year-to-year variation in recruitment.

\section{Standing Crop}

Standing crop was highest $(\mathrm{P}<0.01)$ in year $2(660 \mathrm{~kg} / \mathrm{ha})(\mathrm{Fig}$. 1), following the wet fall and winter of 1984. Dry conditions in summer and fall of year 2 limited regrowth after grazing and mean standing crop at the start of grazing in year 3 was significantly $(\mathrm{P}<0.01)$ lower, at $372 \mathrm{~kg} / \mathrm{ha}$. No treatment by year interaction was observed $(\mathrm{P}=0.26)$. Standing crop of HIGH intensity grazing was significantly $(\mathrm{P}=0.04)$ less than all other treatments, partially because of year 3 when standing crop on HIGH reached only $57 \%$ of CONT, at $269 \mathrm{~kg} / \mathrm{ha}$. During the study, forage standing crop at the start of grazing never dropped below the 225 $\mathrm{kg} / \mathrm{ha}$ yield recommended by Sharp (1970). The lower standing crop recorded for HIGH reflects the more intense level of utilization by the doubled stocking rate.

\section{Tiller Density}

Olson and Richards (1988b) found that heavy grazing during internode elongation reduced survival and recruitment of crested wheatgrass ramets. We noted a similar stocking rate response, wherein crested wheatgrass tiller density was greater $(P=0.10)$ in

Table 1. Monthly precipitation ( $\mathrm{mm}$ ) received during the 4-year grazing study, and the 41-year means for the Northern Great Basin Experimental Range, Harney County, Ore.

\begin{tabular}{lcccccccccccc}
\hline $\begin{array}{l}\text { Crop } \\
\text { year }\end{array}$ & Sept. & Oct. & Nov. & Dec. & Jan. & Feb. & Mar. & Apr. & May & June & July & Aug \\
Total
\end{tabular}




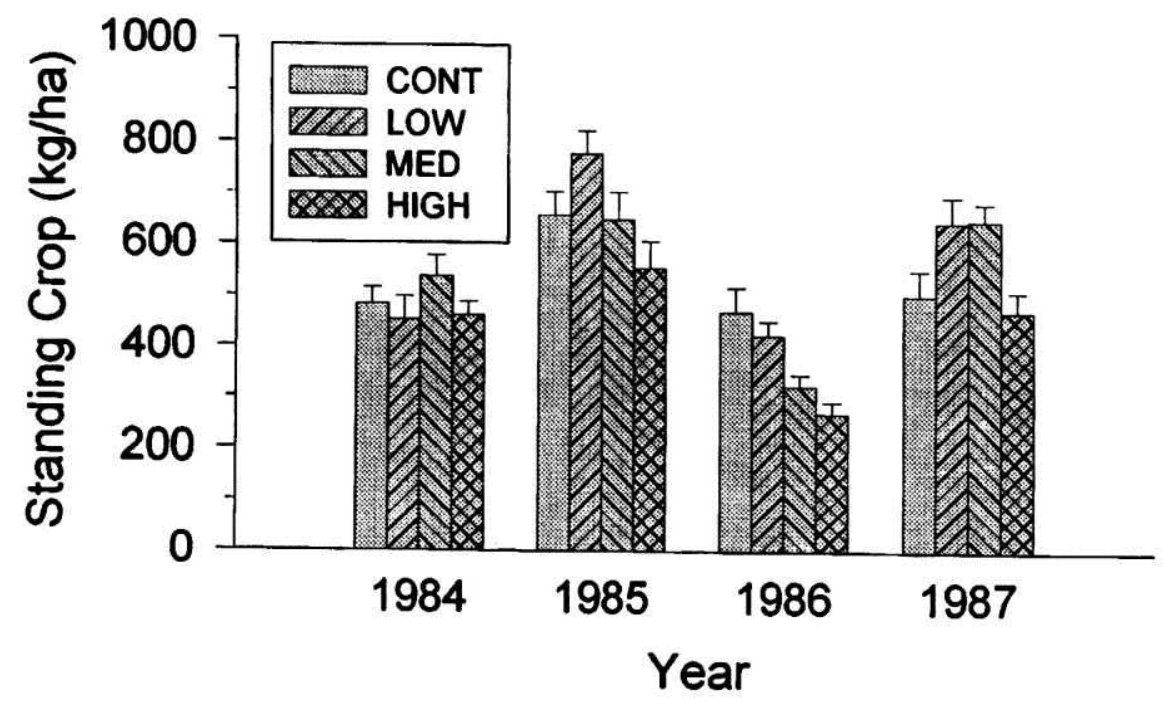

Fig. 1. Standing crop of crested wheatgrass pasture grazed continuously (CONT) for 45 days (0.6 AUM/ha), or with short duration grazing in two 3-day graze periods at 0.6 (LOW), 0.9 (MED), or 1.2 AUM/ha (HIGH). Measurements were taken in May each year during the boot stage of phenology. Vertical bars represent 1 standard error of the mean.

LOW than in the HIGH treatment (Table 2). Crested wheatgrass tiller density in HIGH pastures did not differ from CONT. These findings parallel those of Willms et al. (1990) in Canada wherein crested wheatgrass tiller density after grazing was similar to protected areas. Highest $(\mathrm{P}=0.1)$ tiller density was recorded in the LOW treatment. Based on our data there is no clear indication that tiller density was decreased by short duration grazing at 1.2 AUM/ha. However, there is indication that short duration grazing management at a conventional ( $0.6 \mathrm{AUM} / \mathrm{ha})$ stocking rate increased tiller density of crested wheatgrass. Grazing crested wheatgrass twice in spring has been observed to promote tiller recruitment (Olson and Richards 1988b) and it is possible this was a factor in the higher tiller density observed on the LOW treatment.

Crested wheatgrass tiller recruitment occurs mainly in fall (Mueller and Richards 1986) when environmental conditions moderate and soil water availability increases. Miller and Rose (1992) found that ungrazed crested wheatgrass tiller density increased between fall and the following spring. Overwinter mortality in their study was less than $10 \%$. We did not measure fall tiller recruitment in the present study, however, we assumed that most tillers counted in the spring had initiated growth the previ-

Table 2. Crested wheatgrass tiller density (tillers $/ \mathrm{m}^{2}$ ) in pastures receiving either moderate continuous or short duration grazing at 3 stocking rates. The study was conducted at the Northern Great Basin Experimental Range, 72 km west of Burns, Ore.

\begin{tabular}{lllccc}
\hline \multirow{2}{*}{ Year } & \multicolumn{5}{c}{ Grazing Treatment } \\
\cline { 2 - 4 } & CONT $^{1}$ & LOW & MED & HIGH & Mean \\
\hline 1984 & 544 & 594 & 521 & 515 & $544^{\mathrm{b}}$ \\
1985 & 783 & 909 & 836 & 858 & $847^{\mathrm{a}}$ \\
1986 & 783 & 804 & 849 & 716 & $788^{\mathrm{a}}$ \\
1987 & 438 & 520 & 474 & 469 & $475^{\mathrm{c}}$ \\
Mean & $637^{\mathrm{a}}$ & $707^{\mathrm{b}}$ & $670^{\text {ab }}$ & $640^{\mathrm{a}}$ & \\
\hline
\end{tabular}

CONT, LOW, MED, HIGH are continuous grazing (45 days) at $0.6 \mathrm{AUM} / \mathrm{ha}$, or short duration grazing in two 3-day periods at $0.6,0.9$ or $1.2 \mathrm{AUM} / \mathrm{ha}$, respectively.

a.b Means within a column or row not followed by the same letter are significantly different $(\mathrm{P}<0.05)$. ous fall. Therefore, the tillers reflected an integrated response to both abiotic influences and grazing stress. Significant $(\mathrm{P}<0.001)$ variation in tiller density occurred between years, and densities ranged from a low of 475 tillers $/ \mathrm{m}^{2}$ (year 4 ) to a high of 847 tillers $/ \mathrm{m}^{2}$ (year 2). No treatment by year interaction was noted $(P>0.6)$, which indicated that all treatments responded similarly to environmental conditions each year, even at doubled stocking rate using short duration grazing management.

\section{Shrub Response}

Sagebrush density was low in all treatments (Table 3). No difference $(P=0.6)$ among treatments was observed for plants over

Table 3. Wyoming big sagebrush density (plants $/ 100 \mathrm{~m}^{2}$ ) of large ${ }^{1}$ and small plants growing in crested wheatgrass pastures. Pastures were grazed either continuously or with short duration grazing at 3 stocking rates. The study was conducted at the Northern Great Basin Experimental Range, 72 km west of Burns, Ore.

\begin{tabular}{|c|c|c|c|c|c|}
\hline Year & $\mathrm{CONT}^{2}$ & LOW & MED & HIGH & Mean \\
\hline Large plants & \multicolumn{5}{|c|}{ (plants $\left./ 100 \mathrm{~m}^{2}\right) \ldots \ldots$} \\
\hline 1984 & 5 & 4 & 6 & 7 & $7^{y}$ \\
\hline 1985 & 7 & 5 & 6 & 6 & $6^{y}$ \\
\hline 1986 & 10 & 6 & 8 & 11 & $10^{x}$ \\
\hline 1987 & 10 & 6 & 9 & 12 & $12^{\mathrm{x}}$ \\
\hline Mean & $8^{x}$ & $5^{x}$ & $7^{x}$ & $9^{x}$ & \\
\hline \multicolumn{6}{|l|}{ Small plants ${ }^{3}$} \\
\hline 1984 & $9^{\mathrm{a}}$ & $2^{b}$ & $6^{\mathrm{a}}$ & $7^{\mathrm{a}}$ & 6 \\
\hline 1985 & $9^{a}$ & $2^{b}$ & $6^{a}$ & $6^{\mathrm{a}}$ & 6 \\
\hline 1986 & $4^{b}$ & $3^{b}$ & $7^{\mathrm{ab}}$ & $11^{\mathrm{a}}$ & 6 \\
\hline 1987 & $4^{b}$ & $4^{b}$ & $8^{a b}$ & $12^{\mathrm{a}}$ & 7 \\
\hline Mean & 7 & 3 & 7 & 9 & \\
\hline
\end{tabular}

Large and small plants were $>15$, and $<15-\mathrm{cm}$ tall, respectively.

${ }^{2}$ CONT, LOW, MED, HIGH are continuous grazing (45 days) at $0.6 \mathrm{AUM} / \mathrm{ha}$, or short duration grazing in two 3-day periods at $0.6,0.9$ or $1.2 \mathrm{AUM} / \mathrm{ha}$, respectively.

${ }^{3}$ Treatment by year interaction was significant $(\mathrm{P}=0.02)$ for small plants, so years were analyzed separately.

a,b Means in the same row followed by different letters are significantly different $(\mathrm{P}<0.05)$.

${ }_{x, y}$ Means for year or grazing treatment followed by different letters are significantly different $(\mathbf{P}<0.05)$. 
15-cm tall and no treatment by year interaction was observed $(\mathrm{P}=0.47)$. Increased $(\mathrm{P}<0.001)$ density of larger plants was observed over years, with a significant increase occurring between year 2 and year 3 , perhaps in response to above average precipitation in winter and spring of 1985-86. A significant linear trend for increasing density $(\mathrm{P}<0.01)$ was found for large plants.

Treatment by year interaction was significant $(\mathrm{P}=0.02)$ for small $(<15-\mathrm{cm}$ tall) sagebrush plants. At the beginning of the study, small sagebrush density did not differ $(P>0.05)$ between CONT and HIGH treatments. However, in years 3 and 4 density of small plants in HIGH exceeded both CONT and LOW treatments. Apparently, increased defoliation of crested wheatgrass at the doubled stocking rate enhanced survival of juvenile sagebrush. Miller et al. (1990) found that soil water content during mid June was greatest when crested wheatgrass plants were clipped during the boot stage. That is analogous to the present study wherein grazing began during the boot stage. Increased removal of live tissue at the doubled stocking rate may have decreased soil water depletion by crested wheatgrass, thereby enhancing water availability to juvenile sagebrush.

Small green rabbitbrush plants $(<15 \mathrm{~cm}$ tall $)$ responded with a significant $(\mathrm{P}<0.001)$ density increase between years 2 and 3 (Table 4) while large plants did not differ between years $(P>0.5)$. Plant density between treatments was not different for either large $(\mathrm{P}>0.5)$ or small $(\mathrm{P}>0.6)$ size classes.

Table 4. Green rabbitbrush density (plants $/ 100 \mathrm{~m}^{2}$ ) of large1 and small plants growing in crested wheatgrass pastures. Pastures were grazed either continuously or with short duration grazing at 3 stocking rates. The study was conducted at the Northern Great Basin Experimental Range, 72 km west of Burns, Ore.

\begin{tabular}{|c|c|c|c|c|c|}
\hline Year & $\mathrm{CONT}^{2}$ & LOW & MED & HIGH & Mean \\
\hline \multicolumn{6}{|c|}{- plants $/ 100 \mathrm{~m}^{2}$} \\
\hline 1984 & 9 & 4 & 6 & 7 & $7^{x}$ \\
\hline 1985 & 8 & 4 & 5 & 5 & $5^{x}$ \\
\hline 1986 & 10 & 7 & 8 & 11 & $9^{x}$ \\
\hline 1987 & 9 & 8 & 9 & 12 & $9^{x}$ \\
\hline Mean & $9^{x}$ & $7^{x}$ & $6^{x}$ & $9^{x}$ & \\
\hline \multicolumn{6}{|c|}{ Small plants } \\
\hline 1984 & 7 & 2 & 2 & 3 & $3^{y}$ \\
\hline 1985 & 11 & 6 & 5 & 8 & $8^{y}$ \\
\hline 1986 & 14 & 9 & 12 & 25 & $15^{x}$ \\
\hline 1987 & 18 & 10 & 14 & 19 & $15^{x}$ \\
\hline Mean & $13^{x}$ & $7^{x}$ & $8^{x}$ & $13^{x}$ & \\
\hline
\end{tabular}

Large and small plants were $>15$, and $\leq 15-\mathrm{cm}$ tall, re spectively.

${ }^{2}$ CONT, LOW, MED. HIGH are continuous grazing (45 days) at $0.6 \mathrm{AUM} / \mathrm{ha}$, or short duration grazing in two 3 -day periods at $0.6,0.9$ or $1.2 \mathrm{AUM} / \mathrm{ha}$, respectively.

${ }^{\mathrm{x}, \mathrm{y}}$ Row and column means for year or grazing treatment followed by different letters are significantly different $(P<0.05)$. No treatment by year interaction occurred $(P>0.2)$.

Foliar cover of both sagebrush and rabbitbrush followed observed changes in plant density (Table 5). Sagebrush cover increased significantly $(\mathrm{P}<0.01)$ between 1985 and 1986. Increases in cover between year 2 and 3 are probably attributable to above average precipitation between February and May, 1986 which provided excellent growing conditions that spring. Green rabbitbrush cover also increased significantly $(\mathrm{P}<0.01)$ in year 3 (1986), but later decreased significantly in year 4 . Reasons for the decrease are not clear, however, it may be that rabbitbrush responded to increased spring precipitation in year 3 with an
Table 5. Foliar cover (\%) for Wyoming big sagebrush and green rabbitbrush growing in crested wheatgrass pastures. Pastures were grazed either continuously or with short duration grazing at 3 stocking rates.

\begin{tabular}{lccccc}
\hline \hline & \multicolumn{4}{c}{ Grazing Treatment } \\
\cline { 2 - 4 } Year & CONT $^{1}$ & LOW & MED & HIGH & Mean \\
\hline Big sagebrush & $-\ldots-1$ & -1.9 & - & -1.9 & $1.0^{\mathrm{b}}$ \\
1984 & 0.8 & 0.4 & 1.9 & 1.9 & $0.9^{\mathrm{b}}$ \\
1985 & 0.8 & 0.4 & 1.4 & 1.4 & $1.4^{\mathrm{a}}$ \\
1986 & 1.2 & 0.7 & 2.5 & 2.5 & $1.5^{\mathrm{a}}$ \\
1987 & 1.0 & 0.9 & 2.6 & 2.6 & \\
Mean & $1.0^{\mathrm{a}}$ & $0.6^{\mathrm{a}}$ & $1.1^{\mathrm{a}}$ & $2.1^{\mathrm{a}}$ &
\end{tabular}

Green rabbitbrush

$\begin{array}{llllll}1984 & 1.2 & 0.5 & 0.8 & 1.2 & 0.9^{\mathrm{y}}\end{array}$

$\begin{array}{llllll}1985 & 0.6 & 0.3 & 0.4 & 1.0 & 0.6^{2}\end{array}$

$\begin{array}{llllll}1986 & 1.5 & 0.6 & 1.3 & 2.1 & 1.4^{\mathrm{x}}\end{array}$

$\begin{array}{llllll}1987 & 0.8 & 0.4 & 0.7 & 1.5 & 0.8^{\mathrm{y}}\end{array}$

$\begin{array}{lllll}\text { Mean } & 1.0^{\mathrm{x}} & 0.4^{\mathrm{x}} & 0.8^{\mathrm{x}} & 1.4^{\mathrm{x}}\end{array}$

CONT, LOW, MED, HIGH are continuous grazing (45 days) at 0.6 AUM/ha, or short duration grazing in two 3 -day periods at $0.6,0.9$ or $1.2 \mathrm{AUM} / \mathrm{ha}$, respectively.

${ }_{\mathrm{x}, \mathrm{y}}$ Means in the same column or row followed by different letters are significantly different $(P<0.05)$.

ephemeral increase in leaf area, and later reduced leaf area in year 4 when soils were drier.

\section{Conclusion}

This 4-year study provides new information on the dynamics of grass and shrub response to grazing. Crested wheatgrass tiller density was greatest in short duration grazed pastures using a stocking rate similar to moderate continuous grazing. As stocking rate increased to twice that of moderate continuous grazing, average tiller density was less than for short duration grazing at a conventional stocking rate but did not differ from continuously grazed units. The greatest variation in tiller density was related to abiotic fluctuation each year which variously limited or enhanced tiller development. Sagebrush increased significantly over the 4 year study, however no differences attributable to grazing were found for density and cover of large plants. Small sagebrush responded differently to treatments over time. Density of small plants increased in short duration grazed pastures only at doubled stocking rates. Neither continuous grazing nor short duration grazing at the moderate stocking rate resulted in a significant density change. The reason that small sagebrush density increased with short duration grazing at doubled stocking rate may be attributed to reduced competition for soil water by crested wheatgrass.

These increases in density of small plants could have significant long-term impacts on pasture productivity because as smaller plants establish, sagebrush competition for water and mineral nutrients will intensify, lowering herbaceous production. In contrast to sagebrush, large and small green rabbitbrush did not differ between treatments, but did show an increase in density over time.

Implications for management are that short duration grazing of crested wheatgrass at moderate stocking rates should not result in stand deterioration, in terms of crested wheatgrass yield or tiller density. Nor should it result in increased rates of shrub encroachment into the seeding. However caution must be used if stocking 
rate increases are planned in conjunction with short duration grazing programs on crested wheatgrass. Presently, crested wheatgrass pasture is generally stocked at a rate sufficient to achieve uniform use and avoid development of decadent, ungrazed plants. In the present study, doubling the stocking rate under short duration grazing accelerated increases in sagebrush density, when compared to moderate continuous grazing. A decrease in crested wheatgrass tiller density was also noted as sagebrush density increased. By contrast, short duration grazing at a conventional stocking rate gave no indication of loss of productivity in terms of increased brush density or diminished crested wheatgrass tiller density. Increasing stocking by $50-100 \%$ with short duration grazing cannot be recommended for crested wheatgrass pasture unless the pasture is clearly understocked initially.

\section{Literature Cited}

Cook, C.Wayne and Loren E. Harris. 1968. Nutritive value of seasonal ranges. Utah Agr. Exp. Sta. Bull. 472. Logan, Utah.

Evans, Raymond A., Richard E. Eckert, Jr., and James A. Young. 1986. High technology weed control-Revegetation systems for establishment and maintenance of crested wheatgrass. p. 91-96. In: K.L. Johnson (ed.) Symposium Proc. Crested wheatgrass: it values, problems and myths. Utah State Univ., Logan, Utah.

Heitschmidt, R.K. and C.A. Taylor, Jr. 1991. Livestock production, p. 161-178. In: Rodney K. Heitschmidt and Jerry W. Stuth (eds.). Grazing Management: An Ecological Perspective. Timber Press, Portland, Ore.

Kothmann, M.M. 1980. Integrating livestock needs to the grazing system, p.65-83. In: Kirk C. McDaniel and Cris Allison (eds.) Symposium Proc. Grazing Manage. Systems for S.W. Rangelands, New Mexico St. Univ., Las Cruces, N.M.

Laycock, William A. 1967. How heavy grazing and protection affect sagebrush-grass ranges. J. Range Manage. 20:206-213.

Laycock, W.A. and P.W. Conrad. 1981. Responses of vegetation and cattle to various systems of grazing on seeded and native mountain rangelands in eastern Utah. J. Range Manage. 34:52-56.

Lentz, R.D. and G.H. Simonson. 1986. A detailed soils inventory and associated vegetation of Squaw Butte Range Experiment Station. Spec. Rep. 760. Oregon Agr. Exp. Sta., Corvallis, Ore.

Marlette, G.M. and J.E. Anderson. 1986. Seed banks and propagule dispersal in crested wheatgrass stands. J. Appl. Ecol. 23:161-175.

Miller, Richard F. and Jeffry A. Rose. 1992. Growth and carbon allocation of Agropyron desertorum following autumn defoliation. Oecologia 89:482-486.

Miller, Richard F., Marshall R. Haferkamp, and Raymond F. Angell. 1990. Clipping date effects on soil water and regrowth in crested wheatgrass. J. Range Manage. 43:253-257.

Mueller, R.J. and J.H. Richards. 1986. Morphological analysis of tillering in Agropyron spicatum and Agropyron desertorum. Ann. Bot. 58:911-921.

Olson, B.E. and J.H. Richards. 1988a. Tussock regrowth after grazing: intercalary meristem and axillary bud activity of tillers of Agropyron desertorum. Oikos. 51:374-382.

Olson, B.E. and J.H. Richards. 1988b. Annual replacement of the tillers of Agropyron desertorum following grazing. Oecologia 76:1-6.

Owens, M.K. and B.E. Norton. 1990. Survival of juvenile basin big sagebrush under different grazing regimes. J. Range Manage. 43:132-135.

Petersen, Rodger G. 1985. Design and analysis of experiments. Marcel Dekker, Inc. N.Y.

Robertson, J.H., D.L. Neal, R. McAdams, and P.T. Tueller. 1970. Changes in crested wheatgrass ranges under different grazing treatments. J. Range Manage. 23:27-34.
Sanders, Kenneth D., Lee A. Sharp, and Michacl A. Siebe. 1986 Short duration grazing on crested wheatgrass in southern Idaho, p. 3-8. In: James A. Tiedeman (ed.), Short Duration Grazing: Proc. of the short duration grazing and current issues in grazing management shortcourse. Washington State Univ. Pullman, Wash.

SAS. 1985. SAS user's guide: Basics. SAS Institute, Cary, N.C.

Savory, Allan and Stanley D. Parsons. 1980. The Savory grazing method. Rangelands. 2:234-237.

Sharp, Lee A. 1970. Suggested management programs for grazing crested wheatgrass. Forest, Wildlife and Range Exp. Sta. Univ. of Idaho Bull. \#4.

Sneva, Forrest A. 1977. Correlations of precipitation and temperature with spring, regrowth, and mature crested wheitgrass yields. J. Range Manage. 30:270-275.

Steel, Robert C.D. and James H. Torrie. 1980. Principles and procedures of statistics: A biometrical approach. 2nd. Ed. McGraw-Hill Book Co. N.Y.

Willms, Walter D., Sylver Smoliak, and Johan F. Dormarr. 1990. Vegetation response to time-controlled grazing on Mixed and Fescue Prairie. J. Range Manage. 43:513-517. 